\title{
REMOVAL OF Cd(II) AND Pb(II) FROM AQUEOUS SOLUTIONS BY PISTACHIO HULL WASTE
}

\author{
Mohsen HAMIDPOUR*, Nahid HOSSEINI, Vahid MOZAFARI and \\ Mohammad HESHMATI RAFSANJANI
}

Vali-e-Asr University of Rafsanjan, P.O. Box 518, Rafsanjan, Iran

*Author for correspondence: mohsen_hamidpour@yahoo.com

(Received April 2017; accepted September 2017)

Key words: biosorption, heavy metals, waste materials, pollution

\begin{abstract}
The aim of this study was to use the raw pistachio hull powder for the removal of $\mathrm{Cd}(\mathrm{II})$ and $\mathrm{Pb}$ (II) from aqueous solutions. The kinetic experiments showed that the biosorption of $\mathrm{Cd}(\mathrm{II})$ and $\mathrm{Pb}(\mathrm{II})$ on the adsorbent is rapid, and maximum biosorption capacities were achieved in $2 \mathrm{~h}$. The time-dependent biosorption of $\mathrm{Cd}$ (II) and $\mathrm{Pb}$ (II) onto the adsorbent were well described by both the pseudo-first-order and the pseudosecond-order models. The experimental adsorption capacity $\left(q_{\exp }\right)$ was close to that calculated from these two models. The equilibrium adsorption of $\mathrm{Cd}(\mathrm{II})$ and $\mathrm{Pb}(\mathrm{II})$ was satisfactorily described by the Sips isotherm. The adsorption isotherms showed that the affinity of $\mathrm{Cd}(\mathrm{II})$ and $\mathrm{Pb}$ (II) to the adsorbent increased with $\mathrm{pH}$. Based on the estimates obtained by the Visual MINTEQ code, the $\mathrm{Pb}^{2+}$ and $\mathrm{Cd}^{2+}$ species were the dominant ones in the solutions at $\mathrm{pH} \leq 7.0$ and $\leq 8.5$, respectively. The Fourier transform-infrared results confirmed the interactions between metals and functional groups present on the surface of pistachio hull. These findings show that the raw pistachio hull powder used in this study exhibited a high adsorption capacity for $\mathrm{Cd}(\mathrm{II})$ and $\mathrm{Pb}(\mathrm{II})$, and thus it may be useful for the immobilization of these metals from polluted sites.
\end{abstract}

Palabras clave: bioadsorción, metales pesados, materiales de desecho, contaminación

\section{RESUMEN}

El objetivo de este estudio fue utilizar polvo de cáscara de pistache sin procesar para remover $\mathrm{Cd}(\mathrm{II})$ y $\mathrm{Pb}$ (II) de soluciones acuosas. Los experimentos cinéticos mostraron que la bioadsorción de $\mathrm{Cd}(\mathrm{II})$ y $\mathrm{Pb}(\mathrm{II})$ en el adsorbente es rápida y las capacidades máximas de bioadsorción se alcanzan en $2 \mathrm{~h}$. Se describió ampliamente la bioadsorción dependiente del tiempo de $\mathrm{Cd}$ (II) y $\mathrm{Pb}$ (II) en el adsorbente tanto para el seudomodelo de primer orden como para el de segundo orden. Los valores de la capacidad experimental de adsorción $\left(q_{\exp }\right)$ fueron cercanos a los calculados mediante estos modelos. El equilibrio de adsorción de $\mathrm{Cd}(\mathrm{II})$ y $\mathrm{Pb}(\mathrm{II})$ fue descrito satisfactoriamente por la isoterma de Sips. Las isotermas de adsorción mostraron que la afinidad de $\mathrm{Cd}(\mathrm{II})$ y $\mathrm{Pb}$ (II) por el adsorbente se incrementó con el $\mathrm{pH}$. Con base en las estimaciones obtenidas mediante el código Visual MINTEQ, se encontró que $\mathrm{Pb}^{2+} \mathrm{y} \mathrm{Cd}^{2+}$ fueron las especies dominantes en las soluciones con $\mathrm{pH} \leq 7.0 \mathrm{y} \leq 8.5$, respectivamente. Los resultados de la espectrometría 
infrarroja por transformadas de Fourier confirmaron las interacciones entre los metales y los grupos funcionales presentes en la superficie de la cáscara de pistache. Estos resultados muestran que el polvo de cáscara de pistache sin procesar utilizado en el presente estudio tuvo una alta capacidad de adsorción para $\mathrm{Cd}(\mathrm{II})$ y $\mathrm{Pb}(\mathrm{II})$, y por consiguiente podría ser de utilidad para remover estos metales de sitios contaminados.

\section{INTRODUCTION}

Toxic heavy metals can enter the environment from different natural and anthropogenic sources (Salazar-Camacho and Villalobos-Peñalosa 2017). The presence of toxic heavy metals in aqueous environments can be harmful to humans and living organisms even at low levels (Sparks 2003). Thus, it is essential to remove heavy metals from contaminated waters for protection of the aquatic ecosystem's health.

Various physical and chemical methods are available for removal of heavy metals from wastewaters, including chemical precipitation (Kurniawan et al. 2006), coagulation-flocculation (López-Maldonado et al. 2014), electrochemical treatments (Mohammadi et al. 2005), membrane filtration (Chen et al. 2006), ion exchange (Inglezakis and Poulopoulos 2006, Inglezakis and Loizidou 2007), and biosorption (Milojković et al. 2016). Among these methods, biosorption is an eco-friendly and cost-effective technology for removal of metals contained in effluents (Milojković et al. 2016).

In recent years, different organic materials have been chosen for biosorption of heavy metals from contaminated water (Fomina and Gadd 2014). Among organic materials that exhibit high affinity for metal cations, activated carbon appears to be the most promising, but it is very expensive (Moussavi and Barikbin 2010).

Removal of heavy metals from water and wastewater by raw agricultural waste is a low-cost treatment method (Śćiban et al. 2008). Various raw agricultural waste materials have been used to eliminate toxic heavy metals from contaminated water, such as cork waste (López-Mesas et al. 2011), pistachio byproducts (Moussavi and Barikbin 2010), sugarcane bagasse waste (Ullah et al. 2013), tea waste (Albadarin et al. 2013), tree bark powder (Munagapati et al. 2010), and pine cone shell (Martín-Lara et al. 2016). To utilize the high efficacy and simplicity of biosorption for the treatment of metal contaminated water, further investigation on low-cost biosorbents is essential.
Pistachio (Pistacia vera L.) is an important tree nut crop cultivated in arid and semi-arid regions of the world. Four major pistachio producers in 2014 were Iran (415 $531 \mathrm{t})$, the United States (23 $3146 \mathrm{t})$, Turkey (80 $000 \mathrm{t}$ ) and China (76 943 t) (FAO 2017).

Every year, a large amount of pistachio hull is generated in large quantities as waste, creating environmental problems. For example, approximately $250000 \mathrm{t}$ of pistachio by-products are produced each year in Iran (Moussavi and Barikbin 2010).

Although a large number of studies on the removal of heavy metal ions from water and wastewater using different raw agricultural wastes exist in the literature, every special material requires individual research. Pistachio hull has been evaluated for the removal of dye (Deniz and Kepeki 2016) and chromium (Moussavi and Barikbin 2010) from wastewater. In the present study, an attempt was made to use pistachio hull powder as an inexpensive adsorbent for the removal of $\mathrm{Cd}(\mathrm{II})$ and $\mathrm{Pb}$ (II) ions from aqueous solutions.

Biosorption is a complex process involving different mechanisms and controlled by diverse factors that can interact. Factors such as the solution $\mathrm{pH}$, the nature of adsorbent materials, metal ion concentrations, metal ion properties and ionic strength can affect the adsorption of metal ions by adsorbents (Deniz and Kepeki 2016). A better understanding of the kinetics and effective parameters on biosorption of metals by adsorbents will provide engineers and scientists information to implement better strategies for dealing with contaminated soil and water (Hamidpour et al. 2011).

The ability of pistachio hull powder to remove $\mathrm{Cd}$ (II) and $\mathrm{Pb}$ (II) was investigated as a function of the initial metal ions concentration, the contact time and $\mathrm{pH}$. The equilibrium and kinetic data of biosorption were tested using three isotherm models (Freundlich, Langmuir and Sips) and two kinetic models (pseudofirst-order and pseudo-second-order). The Fourier transform-infrared (FTIR) spectroscopy analysis before and after adsorption of $\mathrm{Cd}(\mathrm{II})$ and $\mathrm{Pb}$ (II) onto pistachio hull was also performed to explain the mechanism of biosorption. 


\section{MATERIALS AND METHODS}

\section{Reagents and adsorbent}

All reagents used were extra pure analytical grades: $\mathrm{Pb}\left(\mathrm{NO}_{3}\right)_{2}, \mathrm{Cd}\left(\mathrm{NO}_{3}\right)_{2}$ and $\mathrm{Ca}\left(\mathrm{NO}_{3}\right)_{2} \cdot 4 \mathrm{H}_{2} \mathrm{O}$ (Merck, Germany). Pistachio hull was obtained from a local pistachio processing factory (Rafsanjan, Iran). The collected sample was washed with deionized water and dried in an oven at $50{ }^{\circ} \mathrm{C}$ for $24 \mathrm{~h}$, grinded, and sieved through a 270 mesh sieve. The cation exchange capacity (CEC) was measured using the Na-acetate method (Rhoads 1986). The CEC of the pistachio hull powder was $77 \mathrm{cmol}_{(+)} / \mathrm{kg}$.

Infrared spectrums of untreated and $\mathrm{Cd}-$ and $\mathrm{Pb}-$ loaded adsorbent were obtained using a FTIR spectrometer (Perkin-Elmer Spectrum 100 FTIR-ATR Spectrometer) in the range of $450-4000 \mathrm{~cm}^{-1}$.

\section{Adsorption procedure}

The adsorption experiments of $\mathrm{Cd}$ and $\mathrm{Pb}$ were separately conducted in batch experiments using $0.1 \mathrm{~g}$ of adsorbent in a background electrolyte and at room temperature $\left(23 \pm 2{ }^{\circ} \mathrm{C}\right)$. The background electrolyte $\left(0.01 \mathrm{M} \mathrm{Ca}\left(\mathrm{NO}_{3}\right)_{2}\right)$ was used to fix the ionic strength of solutions. All samples were prepared in duplicate. Blank samples were prepared without adsorbent for all experiments.

The effects of contact time ( $0-24 \mathrm{~h})$, initial $\mathrm{pH}$ values (pHi 3-10), and initial metal concentration (50-200 $\mathrm{mg} / \mathrm{L}$ for $\mathrm{Cd}[\mathrm{II}]$ and $100-1000 \mathrm{mg} / \mathrm{L}$ for $\mathrm{Pb}[\mathrm{II}]$ ) on the adsorption process were investigated. The $\mathrm{pH}$ values of the suspensions were adjusted to desired values by adding predetermined volumes of $0.03 \mathrm{M} \mathrm{HNO}_{3}$ or $\mathrm{NaOH}$ solutions. The suspension $\mathrm{pH}$ was not adjusted during the experiment and the final pHs of suspensions were measured. Suspensions were shaken for $24 \mathrm{~h}$ with a rotary shaker at a speed of $150 \mathrm{rpm}$. After each adsorption experiment, the suspensions were centrifuged at $5000 \mathrm{~g}$ for $10 \mathrm{~min}$, the supernatant filtered and $\mathrm{Cd}(\mathrm{II})$ and $\mathrm{Pb}$ (II) concentrations were determined by an AAnalyst Perkin-Elmer 200 Atomic Absorption
Spectrophotometer (AAS). The operating conditions of the adsorption experiments are summarized in table I. The metal adsorption capacity of pistachio hull was calculated by the mass balance equation:

$q_{e}=\frac{\left(C_{i}-C_{e}\right) V}{M}$

where $q_{\mathrm{e}}$ is the adsorbed amounts of Cd(II) or $\mathrm{Pb}$ (II) (mg/g), $C_{\mathrm{i}}$ the initial metal concentration in the solution $(\mathrm{mg} / \mathrm{L}), C_{\mathrm{e}}$ the equilibrium metal concentration $(\mathrm{mg} / \mathrm{L}), M$ the mass of the adsorbent used $(\mathrm{g})$, and $V$ the volume of the solute solution (L).

\section{Theoretical basis}

The adsorption kinetic data were tested with the pseudo-first-order and pseudo-second-order models. Eqs. (2) and (3) represent non-linear forms of pseudofirst-order and pseudo-second-order kinetic models, respectively (Ho and McKay 1999).

$q_{e}=\frac{\left(C_{i}-C_{e}\right) V}{M}$

$q_{t}=\frac{q_{e}^{2} k_{2} t}{1+q_{e} k_{2} t}$

where $q_{\mathrm{e}}$ and $q_{\mathrm{t}}$ are the amount of the metal ions adsorbed $(\mathrm{mg} / \mathrm{g})$ at equilibrium and at time $t(\mathrm{~h})$, respectively, and $k_{1}(1 / \mathrm{h})$ and $k_{2}(\mathrm{~g} / \mathrm{mg} / \mathrm{h})$ are the pseudo-first-order and pseudo-second-order equilibrium rate constants, respectively.

On the basis of pseudo-second-order models, the initial adsorption rate $h(\mathrm{mg} / \mathrm{g} / \mathrm{h})$ at $t=0$, can be defined as:

$h=k_{2} q_{e}^{2}$

The Freundlich, Langmuir and Sips isotherms were used to fit the equilibrium data of $\mathrm{Cd}(\mathrm{II})$ and $\mathrm{Pb}$ (II) onto pistachio hull. Eqs. 5-7 represent nonlinear form of Freundlich, Langmuir and Sips isotherms, respectively (Ho et al. 2002).

TABLE I. PARAMETERS AND OPERATING CONDITIONS IN SORPTION EXPERIMENTS

\begin{tabular}{|c|c|c|c|c|c|c|}
\hline \multirow{2}{*}{$\begin{array}{l}\text { Sorption } \\
\text { experiments }\end{array}$} & \multicolumn{2}{|c|}{$\begin{array}{c}\text { Initial metal } \\
\text { concentration }(\mathrm{mg} / \mathrm{L})\end{array}$} & \multicolumn{2}{|c|}{$\mathrm{pH}$ of suspension } & \multirow{2}{*}{$\begin{array}{l}\text { Shaking time } \\
\text { (h) }\end{array}$} & \multirow{2}{*}{$\begin{array}{l}\text { Adsorbent dose } \\
(\mathrm{g} / \mathrm{L})\end{array}$} \\
\hline & $\mathrm{Cd}(\mathrm{II})$ & $\mathrm{Pb}(\mathrm{II})$ & $\mathrm{Cd}(\mathrm{II})$ & $\mathrm{Pb}(\mathrm{II})$ & & \\
\hline Time-dependent & $5-48 *$ & $88.7-883^{*}$ & 5.5 & 5.5 & $0.5-24$ & 10 \\
\hline $\mathrm{pH}$-dependent & 8 & 100 & $3-8$ & $4-10$ & 24 & 10 \\
\hline Isotherm & $50-200$ & $100-1000$ & 5.5 and 6.5 & 5.5 and 6.5 & 24 & 10 \\
\hline
\end{tabular}

${ }^{*}$ Approximately, on the basis of 10 and $100 \%$ of the maximum sorption capacity $\left(\mathrm{SC}_{\max }\right)$ of the biosorbent. The $\mathrm{SC}_{\max }$ of the pistachio hull waste was determined in a preliminary study 
$q_{e}=K_{F} C_{e}^{n_{F}}$

$q_{e}=\frac{q_{m L} K_{L} C_{e}}{1+K_{L} C_{e}}$

$q_{e}=\frac{q_{m S} K_{S} C_{e}^{n_{s}}}{1+K_{S} C_{e}^{n}}$

where $q_{\mathrm{e}}$ and $C_{\mathrm{e}}$ are the amount of adsorbed metal per unit mass of adsorbent $(\mathrm{mg} / \mathrm{g})$ and equilibrium liquid phase concentration $(\mathrm{mg} / \mathrm{L})$, respectively, and $K_{\mathrm{F}}(\mathrm{L} / \mathrm{g})$ and $n_{\mathrm{F}}(-)$ are the Freundlich constants characteristics. $K_{\mathrm{F}}$ and $n_{\mathrm{F}}$ are indicators of adsorption capacity and adsorption intensity, respectively (Hamidpour et al. 2011); $q_{\mathrm{mL}}(\mathrm{mg} / \mathrm{g})$ and $K_{\mathrm{L}}(\mathrm{L} / \mathrm{mg})$ are the Langmuir constant related to the maximum adsorption and energy of adsorption, respectively; and $q_{\mathrm{ms}}$ is the monolayer adsorption capacity $(\mathrm{mg} / \mathrm{g})$, and $K_{\mathrm{s}}(\mathrm{L} / \mathrm{mg})$ is the Sips constant related to energy of adsorption.

The parameters of adsorption kinetics and isotherms were determined by the non-linear curve fitting analysis method using the DataFit statistical software.

Chemical species of $\mathrm{Cd}(\mathrm{II})$ and $\mathrm{Pb}$ (II) in the solutions were also predicted using Visual MINTEQ, a computer code developed to simulate equilibrium processes in aqueous systems (Visual MINTEQ 2013).

\section{RESULTS AND DISCUSSION}

\section{FTIR spectra}

The cell wall of pistachio hull consists of lignin, hemicelluloses and cellulose that have different functional groups in their structure (Deniz and Kepekci 2016). The FTIR spectra of pistachio hull powder before and after $\mathrm{Cd}(\mathrm{II})$ and $\mathrm{Pb}$ (II) adsorption are presented in figure 1 . The broad band around $3393 \mathrm{~cm}^{-1}$ in pure pistachio hull powder is attributed to stretching vibrations of hydroxyl $(-\mathrm{OH})$ and amine $\left(-\mathrm{NH}_{2}\right)$ groups (Moussavi and Barikbin 2010). This peak shifted from 3393 to $3385 \mathrm{~cm}^{-1}$ for Cd(II) and to 3373 $\mathrm{cm}^{-1}$ for $\mathrm{Pb}(\mathrm{II})$ and these bands became more intense after $\mathrm{Cd}(\mathrm{II})$ and $\mathrm{Pb}$ (II) adsorption onto pistachio hull waste. The peaks around 2920 and $2860 \mathrm{~cm}^{-1}$ may be assigned to $\mathrm{C}-\mathrm{H}$ deforming vibration, and the sharp band centered around $1654 \mathrm{~cm}^{-1}$ can be related to the aromatic $\mathrm{C}=\mathrm{O}$ ring stretching or $\mathrm{C}=\mathrm{C}$ stretching vibration of aromatic groups (Moussavi and Barikbin 2010). These peaks were greatly intensified after adsorption of $\mathrm{Cd}(\mathrm{II})$ and $\mathrm{Pb}(\mathrm{II})$. The bands in 1300-
$1100 \mathrm{~cm}^{-1}$ can be attributed to stretching vibrations of C-O and C-H groups (Deniz and Kepekci 2016). After adsorption, a shift in the positions of the C-O and $\mathrm{C}-\mathrm{H}$ group peaks occurred. This shift indicated that the $\mathrm{Cd}(\mathrm{II})$ and $\mathrm{Pb}$ (II) forms chemical bonds with these functional groups of the biosorbent. The sharp and intense peak at $1030 \mathrm{~cm}^{-1}$ can be assigned to the C-O-C, P-O or P-OH stretching (Deniz and Kepekci 2016) which shifted to $1034 \mathrm{~cm}^{-1}$ after adsorption of $\mathrm{Cd}(\mathrm{II})$ and $\mathrm{Pb}$ (II). The FTIR results show that the pistachio hull waste has a variety of functional groups, such as carboxyl, hydroxyl and amine, and these groups are likely involved in the biosorption of Cd(II) and $\mathrm{Pb}(\mathrm{II})$. Generally, biosorption of heavy metal ions onto biosorbents involves complex mechanisms of ion exchange, chelation (surface complexation), and adsorption by physical forces (Park et al. 2010, Fomina and Gadd 2014). Similar findings have been reported for sorption of $\mathrm{Cd}(\mathrm{II}), \mathrm{Cu}(\mathrm{II})$ and $\mathrm{Pb}$ (II) to Acacia leucocephala bark powder (Munagapati et al. 2010) and sorption of $\mathrm{Cr}(\mathrm{VI})$ to pistachio hull waste biomass (Moussavi and Barikbin 2010). Also, the FTIR spectrum of $\mathrm{Pb}$-loaded pistachio hull waste was similar to that observed for Cd(II) (Fig. 1b, c).

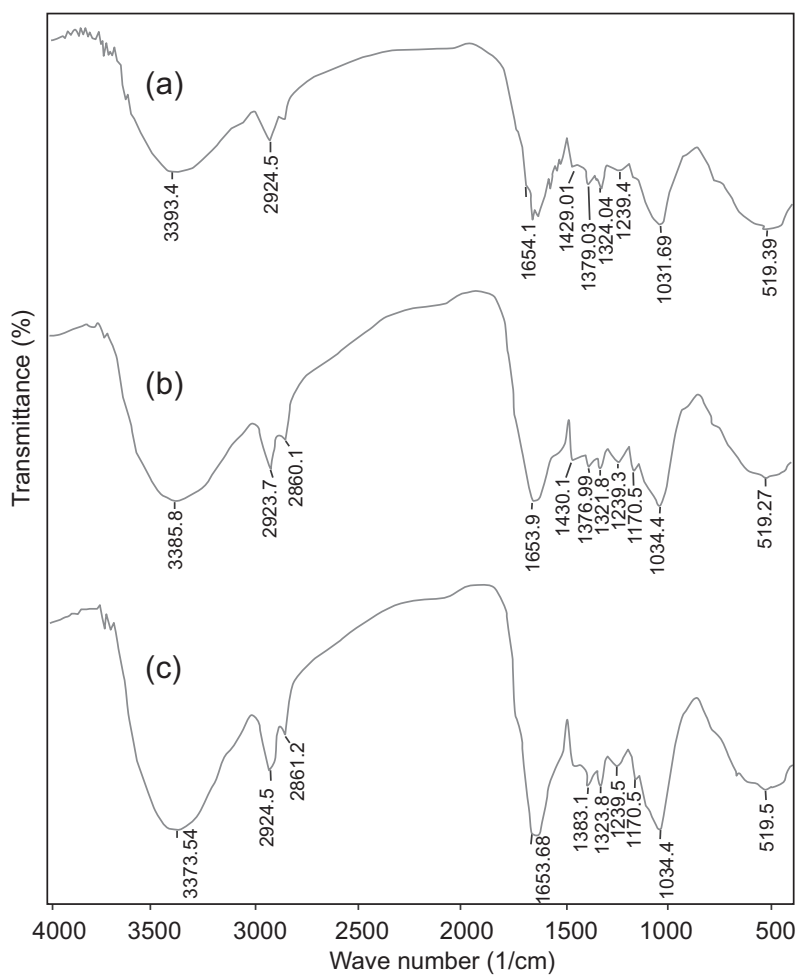

Fig. 1. Fourier transform-infrared spectroscopy spectra of pistachio hull powder: (a) pure, (b) with $\mathrm{Cd}(\mathrm{II})$, and (c) with $\mathrm{Pb}(\mathrm{II})$ 


\section{Kinetics}

The kinetics of adsorption describe the rate of metal removal from a solution and the time required to reach equilibrium, which is important for the understanding of the biosorption process and adsorbent performance. The biosorption capacity of pistachio hull as a function of time and initial concentration of $\mathrm{Cd}(\mathrm{II})$ and $\mathrm{Pb}$ (II) is shown in figure 2. For $\mathrm{Cd}(\mathrm{II})$, the equilibrium was achieved in $30 \mathrm{~min}$ for both initial metal concentrations of 5 and $48 \mathrm{mg} / \mathrm{L}$, where 87 and $90 \%$ of $\mathrm{Cd}(\mathrm{II})$ were adsorbed, respectively. For $\mathrm{Pb}(\mathrm{II})$, the equilibrium was achieved in $120 \mathrm{~min}$ for both initial metal concentrations, where $90 \%$ of $\mathrm{Pb}$ (II) was adsorbed. This may be due to the different initial concentrations of $\mathrm{Cd}(\mathrm{II})$ and $\mathrm{Pb}$ (II) in suspensions. Solutions with lower metal concentration are likely to reach equilibrium in a shorter time period (Hamidpour et al. 2011).

The biosorption kinetics of $\mathrm{Cd}(\mathrm{II})$ and $\mathrm{Pb}$ (II) consisted of two steps (Fig. 2): An initial rapid step where adsorption was very fast, which may be due to an increased number of vacant sites available at the initial stage of the biosorption process, resulting in an increased concentration gradient between the liquid bulk and the adsorbent surfaces (Hamidpour et al. 2011). The second phase is the gradual biosorption stage before the $\mathrm{Cd}(\mathrm{II})$ and $\mathrm{Pb}$ (II) uptake reach
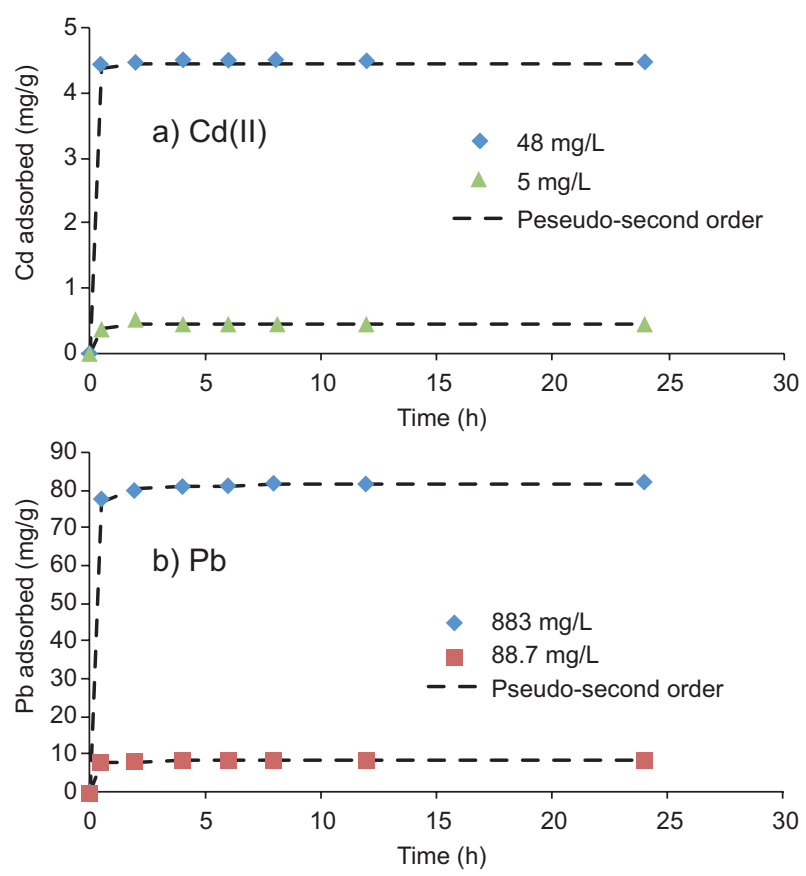

Fig. 2. Effect of initial metal concentration on kinetics of: (a) $\mathrm{Cd}(\mathrm{II})$, and (b) $\mathrm{Pb}$ (II) adsorption onto pistachio hull ( $\mathrm{pH}$ $=5.5$, adsorbent dose $=10 \mathrm{~g} / \mathrm{L}$, temp $=23 \pm 2{ }^{\circ} \mathrm{C}$ ) equilibrium. The concentration gradient is reduced with increasing contact time because of the accumulation of $\mathrm{Cd}(\mathrm{II})$ and $\mathrm{Pb}$ (II) on the vacant adsorption sites, which leads to a decreased adsorption rate of metals at the later stages of adsorption (Singh and Balomajumder 2016).

An increase in initial concentration of $\mathrm{Cd}(\mathrm{II})$ and $\mathrm{Pb}$ (II) leads to an increase in the adsorption capacity of pistachio hull biomass. As the initial metal concentration increased from $5 \mathrm{mg} / \mathrm{L}$ to $48 \mathrm{mg} / \mathrm{L}$ for $\mathrm{Cd}(\mathrm{II})$ and from $88.7 \mathrm{mg} / \mathrm{L}$ to $883 \mathrm{mg} / \mathrm{L}$ for $\mathrm{Pb}(\mathrm{II})$, the experimentally observed adsorption capacity $\left(q_{\text {exp }}\right)$ increased from 0.4 to $4.5 \mathrm{mg} / \mathrm{g}$ and from 8.1 to 82.2 $\mathrm{mg} / \mathrm{g}$ for $\mathrm{Cd}(\mathrm{II})$ and $\mathrm{Pb}(\mathrm{II})$, respectively. Increasing initial metal concentration accelerates the diffusion of $\mathrm{Cd}$ (II) and $\mathrm{Pb}$ (II) from the solution onto the surface of the adsorbent due to the increasing driving force at higher metal concentrations (Hamidpour et al. 2011).

Table II shows the kinetic parameters of the pseudo-first-order and pseudo-second-order models obtained using the non-linear least-square analysis method. The results show that both models satisfactorily described the time-dependent $\mathrm{Cd}$ (II) and $\mathrm{Pb}$ (II) adsorption onto pistachio hull $\left(\mathrm{R}^{2} \geq 0.99\right)$ and the experimental adsorption capacity $\left(q_{\exp }\right)$ were close to that calculated from the these models (Table II). The fitness of experimental data to both the pseudo-

TABLE II. KINETIC PARAMETERS OBTAINED USING PSEUDO-FIRST-ORDER AND PSEUDO-SECOND-ORDER KINETIC MODELS

\begin{tabular}{|c|c|c|c|c|}
\hline \multirow{2}{*}{$\begin{array}{l}\text { Models } \\
\text { constant }\end{array}$} & \multicolumn{2}{|c|}{$\mathrm{Cd}(\mathrm{II})$} & \multicolumn{2}{|c|}{$\mathrm{Pb}(\mathrm{II})$} \\
\hline & $5 \mathrm{mg} / \mathrm{L}$ & $48 \mathrm{mg} / \mathrm{L}$ & $88.7 \mathrm{mg} / \mathrm{L}$ & $883 \mathrm{mg} / \mathrm{L}$ \\
\hline$q_{\exp }(\mathrm{mg} / \mathrm{g})$ & 0.46 & 4.5 & 8.2 & 89.0 \\
\hline \multicolumn{5}{|c|}{ Pseudo-first-order } \\
\hline$q_{\mathrm{e}}(\mathrm{mg} / \mathrm{g})$ & 0.46 & 4.4 & 8.2 & 88.2 \\
\hline$k_{1}(1 / \mathrm{h})$ & 3.4 & 3.65 & 5.1 & 5.9 \\
\hline $\mathrm{R}^{2}$ & 0.99 & 0.99 & 0.99 & 0.99 \\
\hline SSE & 0.03 & 0.02 & 0.06 & 0.68 \\
\hline \multicolumn{5}{|c|}{ Pseudo-second-order } \\
\hline$q_{\mathrm{e}}(\mathrm{mg} / \mathrm{g})$ & 0.46 & 4.45 & 8.2 & 81.65 \\
\hline$k_{2}(\mathrm{~g} / \mathrm{mg} / \mathrm{h})$ & 25.7 & 33.1 & 2.6 & 0.39 \\
\hline$h(\mathrm{mg} / \mathrm{g} / \mathrm{h})$ & 5.43 & 565 & 174.0 & 2603 \\
\hline $\mathrm{R}^{2}$ & 0.99 & 0.99 & 0.99 & 0.99 \\
\hline SEE & 0.03 & 0.02 & 0.02 & 0.37 \\
\hline
\end{tabular}

$q_{\text {exp }}$ : experimentally observed adsorption capacity, $q_{\mathrm{e}}$ : solid phase metal ion concentration at equilibrium, $k_{1}$ : pseudo-first-order rate constant, $k_{2}$ : pseudo-second-order rate constant, $h$ : initial adsorption rate, $\mathrm{R}^{2}$ : correlation coefficient, SEE: standard error of the estimate 
first-order and pseudo-second-order kinetic models indicates that both physical and chemical interactions between the metals ions and pistachio hull biomass are necessary for the adsorption process. Good correlations of experimental data with the pseudo-first-order and pseudo-second-order kinetic models have been reported for the biosorption of $\mathrm{Pb}$ (II) and $\mathrm{Cd}(\mathrm{II})$ on Acacia leucocephala bark powder (Munagapati et al. 2010) and cork waste biomass (López-Mesas et al. 2011).

As shown in table I, the values of the initial biosorption rate $(h)$ and the pseudo-second-order rate constant $\left(k_{2}\right)$ decreased with the increase in initial $\mathrm{Cd}(\mathrm{II})$ and $\mathrm{Pb}$ (II) concentrations, indicating that the solution with lower metal concentration is likely to reach equilibrium in a shorter time period. Hamidpour et al. (2011) reported similar findings for $\mathrm{Cd}(\mathrm{II})$ and $\mathrm{Pb}(\mathrm{II})$ adsorption from aqueous solutions onto zeolite and bentonite.

\section{Effects of the equilibrium pH of the solution}

The $\mathrm{pH}$ value of a liquid solution is the most important factor in the biosorption of metal ions (Ullah et al. 2013). The effect of $\mathrm{pH}$ on the amount of metal removal efficiency depended on the kind of metal. The biosorption capacity of Cd(II) increased with an increase in the $\mathrm{pH}$ of the aqueous solution (Fig. 3a). The biosorption efficiency increased from $61.2 \%$ at $\mathrm{pH} 3.2$ to $95.0 \%$ at $\mathrm{pH} 8.0$ and maximum removal of $\mathrm{Cd}(\mathrm{II})$ by the adsorbent was found at $\mathrm{pH}$ range of 7.0-8.0.

For $\mathrm{Pb}(\mathrm{II})$, two separate sections could be observed (Fig. 3b). Between pH 3.0 and pH 8.0, adsorption efficiency of pistachio hull slightly increased. In the second section $(\mathrm{pH}>8)$ the adsorption efficiency decreased from 97 to $87 \%$.

In order to interpret the effect of $\mathrm{pH}$ on the biosorption behavior of $\mathrm{Cd}(\mathrm{II})$ and $\mathrm{Pb}$ (II) ions onto pistachio hull, knowledge of the metal speciation is essential. The results of Visual MINTEQ indicated that $\mathrm{Pb}^{2+}$ and $\mathrm{Cd}^{2+}$ were the dominant species present in solutions in $\mathrm{pH} \leq 7.0$ and $\mathrm{pH} \leq 8.5$, respectively (Fig. 4a, b). Therefore, the lower adsorption of $\mathrm{Cd}(\mathrm{II})$ and $\mathrm{Pb}$ (II) ions at acidic $\mathrm{pHs}$ is probably due to the presence of excess $\mathrm{H}^{+}$ions competing with the $\mathrm{Cd}^{2+}$ and $\mathrm{Pb}^{2+}$ species for the adsorption sites (López-Mesas et al. 2011). With the increase of the $\mathrm{pH}$ of the solution, the functional groups on surfaces of the adsorbent become negatively charged favoring $\mathrm{Cd}(\mathrm{II})$ and $\mathrm{Pb}$ (II) species adsorption (Sparks 2003). For $\mathrm{Pb}(\mathrm{II})$, the results of speciation showed that soluble hydroxylated species such as $\mathrm{Pb}(\mathrm{OH})^{+}$, $\mathrm{Pb}(\mathrm{OH})_{2}{ }^{\circ}$ and $\mathrm{Pb}_{3}(\mathrm{OH})_{4}{ }^{2+}$ were the major species at
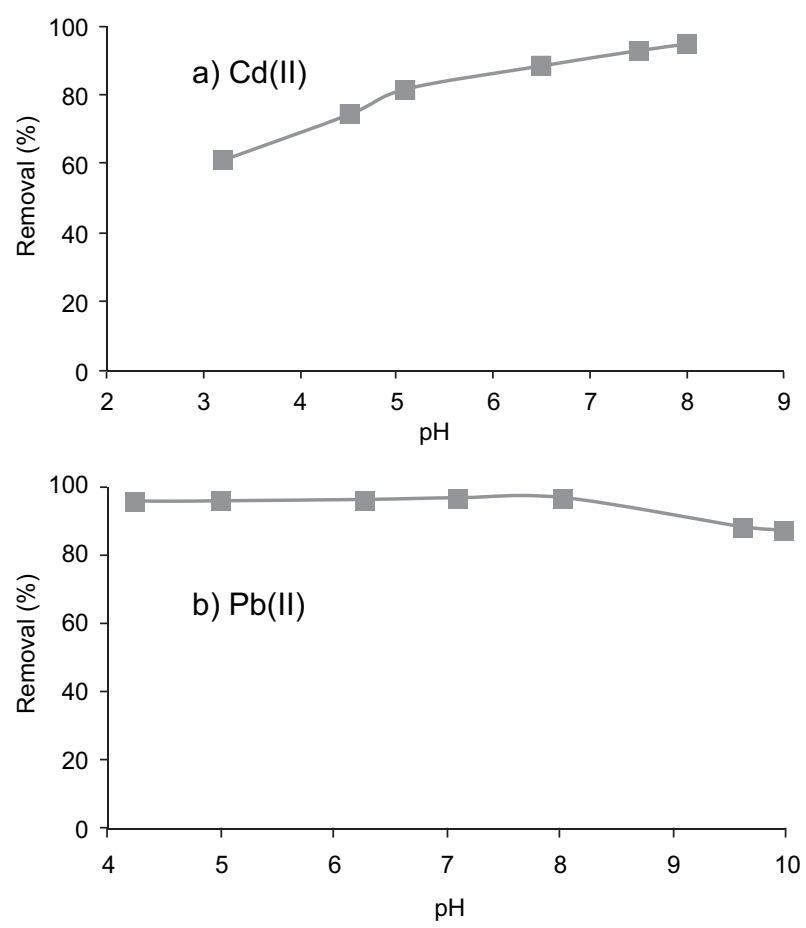

Fig. 3. Effect of final $\mathrm{pH}$ of suspension on percent removal of: (a) $\mathrm{Cd}(\mathrm{II})$, and (b) $\mathrm{Pb}$ (II) by pistachio hull (contact time $=24 \mathrm{~h}$, adsorbent dose $=10 \mathrm{~g} / \mathrm{L}$, temp $=23 \pm 2{ }^{\circ} \mathrm{C}$, $\mathrm{Cd}(\mathrm{II})$ concentration $=8 \mathrm{mg} / \mathrm{L}, \mathrm{Pb}(\mathrm{II})$ concentration $=$ $100 \mathrm{mg} / \mathrm{L}$ )
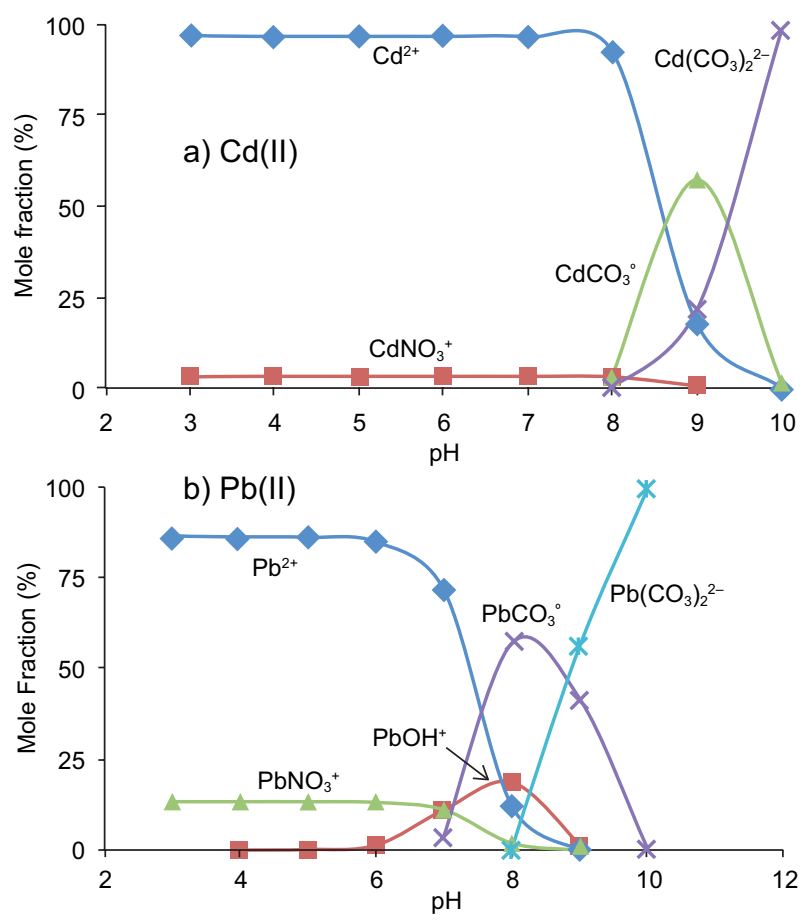

Fig. 4. Chemical speciation of: (a) $\mathrm{Cd}(\mathrm{II})$, and (b) $\mathrm{Pb}(\mathrm{II})$ calculated by Visual MINTEQ software 
$\mathrm{pHs} \geq 8.0$. Lower adsorption of $\mathrm{Pb}(\mathrm{II})$ at $\mathrm{pHs} \geq 8.0$ may be attributed to the formation of these soluble species. Munagapati et al. (2010) reported similar findings for $\mathrm{Pb}$ (II) biosorption from aqueous solutions onto Acacia leucocephala bark powder. According to Visual MINTEQ, none of the suspensions were super-saturated with regard to solid phases of $\mathrm{Cd}(\mathrm{II})$ or $\mathrm{Pb}(\mathrm{II})$. However, the under saturation of the systems does not exclude the possibility of metal surface precipitation or co-precipitation processes (McBride, 2000). The formation of solid phases of $\mathrm{Cd}(\mathrm{OH})_{2}, \mathrm{CdCO}_{3}, \mathrm{~Pb}(\mathrm{OH})_{2}, \mathrm{PbCO}_{3}$, and $\mathrm{Pb}_{3}(\mathrm{OH})_{2}\left(\mathrm{CO}_{3}\right)_{2}$ is probable. Therefore, processes such as electrostatic attraction, the binding of Cd(II) and $\mathrm{Pb}$ (II) to functional groups of the adsorbent and precipitation may be responsible for the removal of $95 \%$ of $\mathrm{Cd}(\mathrm{II})$ and $\mathrm{Pb}(\mathrm{II})$ from solutions for $\mathrm{pHs}$ in the range of 7.0-8.0.

\section{Adsorption isotherms}

The analysis of the equilibrium adsorption data is important to develop a model which correctly describes the results and which could be used for design purposes. In this study, adsorption isotherms were fitted to the Freundlich, Langmuir and Sips equations using non-linear least-square analysis. Fitted models parameters, coefficients of determination $\left(\mathrm{R}^{2}\right)$ and standard errors of estimate (SEE) for adsorption of $\mathrm{Cd}(\mathrm{II})$ and $\mathrm{Pb}$ (II) are shown in table III. On comparison of SEEs and correlation coefficient values $\left(\mathrm{R}^{2}\right)$, the Sips model correctly simulates the adsorption behavior of $\mathrm{Cd}(\mathrm{II})$ and $\mathrm{Pb}$ (II) onto pistachio hull (Figs. 5 and 6). This indicates that the adsorption process of $\mathrm{Cd}(\mathrm{II})$ and $\mathrm{Pb}$ (II) onto the adsorbent followed a combined Freundlich and Langmuir isotherm. The maximum adsorption capacities for the Sips isotherm increased from 84.6 to $92.4 \mathrm{mg} / \mathrm{g}$ and from 7.2 to 9.4 $\mathrm{mg} / \mathrm{g}$ with an increase in the $\mathrm{pH}$ of the suspension from 5.5 to 6.5 for $\mathrm{Pb}$ (II) and $\mathrm{Cd}(\mathrm{II})$, respectively. The values of maximum adsorption capacities obtained using the Sips isotherm were very close to the experimental values.

The Langmuir and Freundlich isotherms fitted the equilibrium adsorption data well, confirming heterogeneous biosorption mechanisms (Hamidpour et al. 2011). The " $n$ " values of the Freundlich isotherm were between 0 and 1 , which demonstrated the suitability of pistachio hull as a biosorbent for removal of $\mathrm{Cd}$ (II) and $\mathrm{Pb}$ (II) from polluted water (Hamidpour et al. 2011). Also, the suitability of pistachio hull as a biosorbent for $\mathrm{Cd}(\mathrm{II})$ and $\mathrm{Pb}(\mathrm{II})$ was assessed using a dimensionless separation factor (RL), which was derived from the Langmuir model by the following relationship (Hamidpour et al. 2011):

TABLE III. ADSORPTION ISOTHERMS CONSTANTS AND STATISTICAL COMPARISON VALUES FOR DIFFERENT MODELS

\begin{tabular}{llcccccc}
\hline \multirow{2}{*}{ Models } & \multirow{2}{*}{ Constants } & \multicolumn{2}{c}{$\mathrm{Pb}(\mathrm{II})$} & & \multicolumn{2}{c}{$\mathrm{Cd}(\mathrm{II})$} \\
\cline { 3 - 4 } \cline { 6 - 7 } & & $\mathrm{pH}=5.5$ & $\mathrm{pH}=6.5$ & & $\mathrm{pH}=5.5$ & $\mathrm{pH}=6.5$ \\
\cline { 7 - 8 } \cline { 6 - 7 } Freundlich & $K_{\mathrm{F}}(\mathrm{L} / \mathrm{g})$ & 3.6 & 4.77 & & 0.77 & 0.99 \\
& $n_{\mathrm{F}}(-)$ & 0.94 & 0.83 & & 0.71 & 0.92 \\
& $\mathrm{R}^{2}$ & 0.81 & 0.89 & & 0.93 & 0.96 \\
& $\mathrm{SEE}$ & 12.4 & 9.5 & & 0.80 & 0.50 \\
\hline \multirow{2}{*}{ Langmuir } & $q_{\mathrm{mL}}(\mathrm{mg} / \mathrm{g})$ & 142.0 & 127.9 & & 14.9 & 20.3 \\
& $K_{\mathrm{L}}(\mathrm{L} / \mathrm{mg})$ & 0.038 & 0.044 & & 0.03 & 0.06 \\
& $\mathrm{R}^{2}$ & 0.91 & 0.95 & & 0.95 & 0.94 \\
& $\mathrm{SEE}$ & 9.2 & 6.4 & & 0.6 & 0.69 \\
\hline \multirow{2}{*}{ Sips } & $q_{\mathrm{s}}(\mathrm{mg} / \mathrm{g})$ & 84.6 & 92.49 & & 7.9 & 9.4 \\
& $K_{\mathrm{S}}(\mathrm{L} / \mathrm{mg})$ & 0.004 & 0.019 & & 0.00004 & 0.03 \\
& $n_{\mathrm{S}}(-)$ & 2.3 & 1.59 & & 4.03 & 2.3 \\
& $\mathrm{R}^{2}$ & 0.98 & 0.97 & & 0.97 & 0.99 \\
& $\mathrm{SEE}$ & 5.02 & 5.2 & & 0.7 & 0.36 \\
\hline
\end{tabular}

$K_{\mathrm{F}}$ : Freundlich isotherm constant related to adsorption capacity, $n_{\mathrm{F}}$ : Freundlich isotherm exponent, $q_{\mathrm{mL}}$ : Langmuir monolayer adsorption capacity, $K_{\mathrm{L}}$ : Langmuir isotherm constant, $q_{\mathrm{s}}$ : Sips monolayer adsorption capacity, $K_{\mathrm{s}}$ : Sips isotherm constant, $n_{\mathrm{s}}$ : Sips isotherm exponent, $\mathrm{R}^{2}$ : correlation coefficient, SEE: standard error of the estimate 

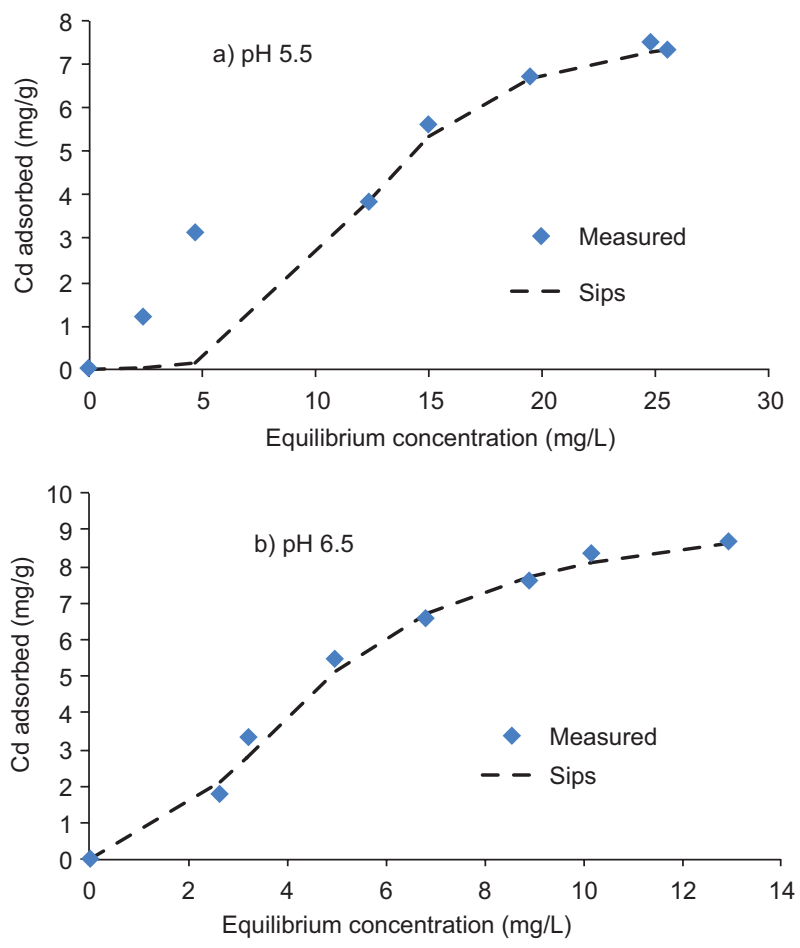

Fig. 5. Sips isotherm for biosorption of $\mathrm{Cd}(\mathrm{II})$ onto pistachio hull at: (a) $\mathrm{pH} 5.5$, and (b) $\mathrm{pH} 6.5$ (contact time $=24 \mathrm{~h}$, adsorbent dose $=10 \mathrm{~g} / \mathrm{L}$, temp $=23 \pm 2{ }^{\circ} \mathrm{C}$ )

$R L=\frac{1}{1+K_{l} C_{i}}$

The RL values for $\mathrm{Cd}(\mathrm{II})$ and $\mathrm{Pb}(\mathrm{II})$ adsorption onto pistachio hull were in the range of $0-1$, which indicates that the biosorption process is favorable at studied conditions.

The values of the Freundlich adsorption capacity $\left(K_{\mathrm{F}}\right)$ increased from 3.6 to $4.7 \mathrm{~L} / \mathrm{g}$ for $\mathrm{Pb}(\mathrm{II})$ and from 0.77 to $0.99 \mathrm{~L} / \mathrm{g}$ for $\mathrm{Cd}(\mathrm{II})$, with an increase in the $\mathrm{pH}$ of the solution from 5.5 to 6.5 (Table III). The same trend is observed for the values of Langmuir adsorption energy $\left(K_{\mathrm{L}}\right)$ for both $\mathrm{Cd}(\mathrm{II})$ and $\mathrm{Pb}(\mathrm{II})$. As the $\mathrm{pH}$ of the suspension increases, the number of negatively charged sites on the adsorbent increase. This favors the adsorption of $\mathrm{Cd}(\mathrm{II})$ and $\mathrm{Pb}$ (II) ions through the electrostatic force of attraction and chelating of metals with the surface functional groups of the adsorbent. Also, surface precipitation of $\mathrm{Cd}(\mathrm{II})$ and specially $\mathrm{Pb}(\mathrm{II})$ ions should be considered as another mechanism at higher $\mathrm{pHs}$ in the solution.

Several researchers have studied the adsorption capacity of biosorbents. However, the comparison of the pistachio hull biosorption capacity with other biosorbents reported in the literature is difficult because
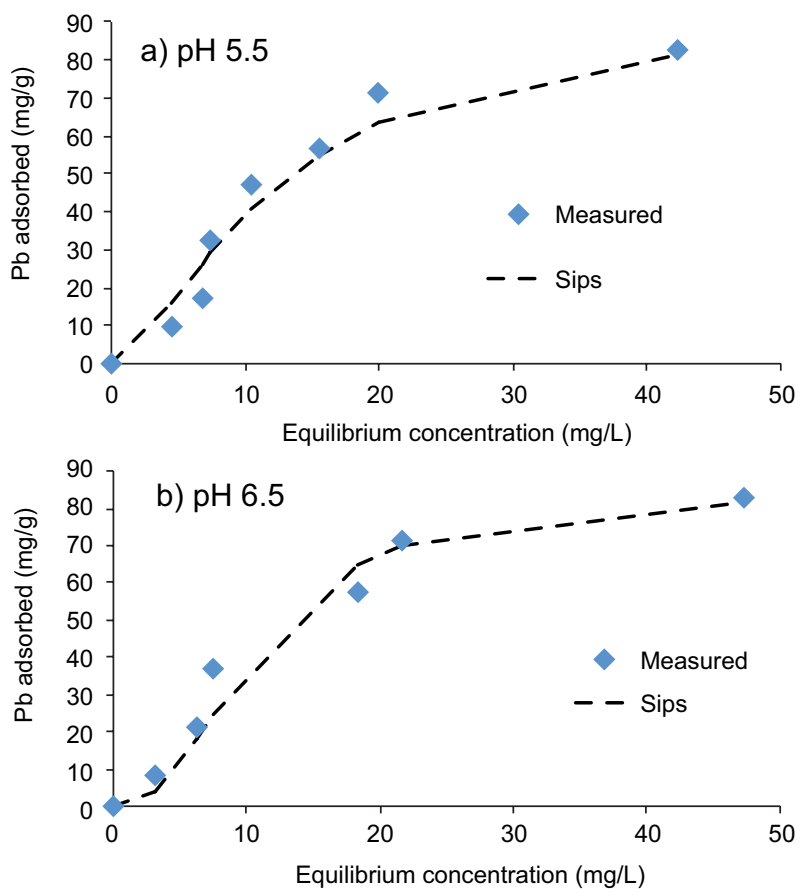

Fig. 6. Sips isotherm for biosorption of $\mathrm{Pb}(\mathrm{II})$ onto pistachio hull at a) $\mathrm{pH} 5.5$ and b) $\mathrm{pH} 6.5$ (contact time $=24 \mathrm{~h}$, adsorbent dose $=10 \mathrm{~g} / \mathrm{L}$, temperature $=23 \pm 2{ }^{\circ} \mathrm{C}$ )

of the different experimental conditions (e.g., initial metal concentration, $\mathrm{pH}$ of the solution, temperature) applied in those studies. The adsorption capacity of pistachio hull for the removal of $\mathrm{Cd}(\mathrm{II})$ and $\mathrm{Pb}(\mathrm{II})$ has been compared with those of other biosorbents reported in literature (Table IV). The values were reported in the form of monolayer adsorption capacity. The experimental data of the present study show that the pistachio hull used in this study exhibited a reasonable adsorption capacity for $\mathrm{Cd}(\mathrm{II})$ and $\mathrm{Pb}$ (II), therefore, may be useful for removal of these metals from polluted environmental sites. Furthermore, the pistachio hull used in this study is a raw material (without modification) that can be easily obtained from pistachio processing industries in large amounts at no cost.

\section{CONCLUSIONS}

Pistachio hull powder showed a high biosorption behavior for removing $\mathrm{Cd}(\mathrm{II})$ and $\mathrm{Pb}$ (II) from aqueous solutions without chemical modification. Biosorption of $\mathrm{Cd}(\mathrm{II})$ and $\mathrm{Pb}(\mathrm{II})$ is $\mathrm{pH}$-dependent showing a maximum value at $\mathrm{pH}$ 8.0. Kinetic and equilibrium studies reveal that the pseudo-first-order and pseudo-second-order kinetic models gave the 
TABLE IV. COMPARISON OF LANGMUIR BIOSORPTION CAPACITIES OF SOME BIOSORBENTS FOR Cd(II) AND Pb(II)

\begin{tabular}{lllll}
\hline Adsorbent & & $q_{\mathrm{mL}}(\mathrm{mg} / \mathrm{g})$ & $\mathrm{pH}$ & References \\
\hline Pine cone shell & $\mathrm{Pb}(\mathrm{II})$ & 25.4 & 5.0 & (Martín-Lara et al. 2016) \\
Cork waste & $\mathrm{Pb}(\mathrm{II})$ & 13.57 & 5.0 & (Lopez-Mesas et al. 2011) \\
Cork waste & $\mathrm{Cd}(\mathrm{II})$ & 2.39 & 5.0 & (Lopez-Mesas et al. 2011) \\
Pine cone shell & $\mathrm{Pb}(\mathrm{II})$ & 25.24 & 5.0 & (Martín-Lara et al. 2016) \\
Wheat straw & $\mathrm{Cd}(\mathrm{II})$ & 14.6 & 6.0 & (Dang et al. 2009) \\
Pistachio hull & $\mathrm{Cd}(\mathrm{II})$ & 14.9 & 5.5 & This study \\
Pistachio hull & $\mathrm{Pb}(\mathrm{II})$ & 142.0 & 5.5 & This study \\
\hline
\end{tabular}

$q_{\mathrm{mL}}$ : Langmuir monolayer adsorption capacity

best fit, and the Sips adsorption model described the interaction between $\mathrm{Cd}(\mathrm{II})$ and $\mathrm{Pb}$ (II) and the adsorbent better than the Freundlich and Langmuir models. The FTIR results confirmed the interactions between metals and functional groups present on the surface of the pistachio hull. These findings showed that the pistachio hull biomass can be used as a cheap and eco-friendly biosorbent for efficient removal of $\mathrm{Cd}(\mathrm{II})$ and $\mathrm{Pb}(\mathrm{II})$ from water. Although, pistachio hull powder showed high sorption capacity for $\mathrm{Cd}(\mathrm{II})$ and $\mathrm{Pb}(\mathrm{II})$, more studies should be carried out for recovery of metals and regeneration and reuse of the material. Moreover, further experiments should be performed at the pilot scale to examine the feasibility of pistachio hull waste for industrial applications.

\section{ACKNOWLEDGMENTS}

The authors greatly acknowledge the Vali-e-Asr University of Rafsanjan for the financial support of this research.

\section{REFERENCES}

Albadarin A.B., Mangwandi C., Walker G.M., Allen S.J., Ahmad M.N.M. and Khraisheh M. (2013). Influence of solution chemistry on $\mathrm{Cr}(\mathrm{VI})$ reduction and complexation onto date-pits/tea-waste biomaterials. J. Environ. Manage. 114, 190-201.

DOI: 10.1016/j.jenvman.2012.09.017

Chen J.P, Mou H., Wang L.K. and Matsuura T. (2006). Membrane filtration. In: Advanced physicochemical treatment processes (Wang L.K., Hung Y.T. and Shammas N.K., Eds.). Humana Press, Totowa, USA, pp. 203-260.

Dang V.B.H., Doan H.D., Dang-Vu T. and Lohi A. (2009). Equilibrium and kinetics of biosorption of cadmium(II) and copper(II) ions by wheat straw. Bioresource Technol. 100 (1), 211-219.

DOI: 10.1016/j.biortech.2008.05.031

Deniz F. and Kepekci R.A. (2016). Dye biosorption onto pistachio by-product: A green environmental engineering approach. J. Mol. Liq. 219, 194-200.

DOI: 10.1016/j.molliq.2016.03.018

FAO (2017). FAOSTAT. Food and Agricultural Organization of the United Nations [online]. http://www.fao.org/ faostat/en/\#data/QC/visualize 10/02/2016.

Fomina M. and Gadd G.M. (2014). Biosorption: Current perspectives on concept, definition and application. Bioresource Technol. 160, 3-14.

DOI: 10.1016/j.biortech.2013.12.102

Hamidpour M., Kalbasi M., Afyuni M. and Shariatmadari H. (2011). Sorption of lead on Iranian bentonite and zeolite: Kinetics and isotherms. Environ. Earth Sci. 62 (3), 559-568. DOI: 10.1007/s12665-010-0547-x

Ho Y.S. and McKay G. (1999). Pseudo-second-order model for sorption processes. Process Biochem. 34 (5), 451-465.

DOI: $10.1016 / \mathrm{S} 0032-9592(98) 00112-5$

Ho Y.S., Porter J. and McKay G. (2002). Equilibrium isotherm studies for the sorption of divalent metal ions onto peat: Copper, nickel and lead single component systems. Water Air Soil Pollut. 141 (1-4), 1-33.

DOI: $10.1023 / \mathrm{A}: 1021304828010$

Inglezakis V.J. and Poulopoulos S.G. (2006). Adsorption, ion exchange and catalysis-design of operations and environmental applications. Elsevier, Amsterdam, The Netherlands, 614 pp.

Inglezakis V.J. and Loizidou M.D. (2007). Ion exchange of some heavy metal ions from polar organic solvents into zeolite. Desalination 211 (1-3), 238-248.

DOI: $10.1016 /$ j.desal.2006.02.094

Kurniawan T.A., Chan G.Y.S., Lo W.H. and Babel S. (2006). Physicochemical treatment techniques for wastewater laden with heavy metals. Chem. Eng. J. 118 (1-2), 83-98. DOI: 10.1016/j.cej.2006.01.015 
López-Maldonado E., Oropeza-Guzmán M.T., JuradoBaizaval J.L. and Ochoa-Terán A. (2014). Coagulationflocculation mechanisms in wastewater treatment plants through zeta potential measurements. J. Hazard. Mater. 279, 1-10. DOI: 10.1016/j.jhazmat.2014.06.025

López-Mesas M., Navarrete E.R., Carrillo F. and Palet C. (2011). Bioseparation of $\mathrm{Pb}(\mathrm{II})$ and $\mathrm{Cd}(\mathrm{II})$ from aqueous solution using cork waste biomass. Modeling and optimization of the parameters of the biosorption step. Chem. Eng. J. 174 (1), 9-17.

DOI: 10.1016/j.cej.2011.07.026

Martín-Lara M.A., Blázquez G., Calero M., Almendros A.I. and Ronda A. (2016). Binary biosorption of copper and lead onto pine cone shell in batch reactors and in fixed bed columns. Int. J. Miner. Process. 148, 72-82. DOI: 10.1016/j.minpro.2016.01.017

McBride M.B. (2000). Chemisorption and precipitation reactions. In: Handbook of soil science. (Sumner M.E., Ed.). CRC Press, Boca Raton, USA, pp. B265-B302.

Milojković J., Pezo L., Stojanović M., Mihajlović M., Lopičić Z., Petrović J., Stanojević M. and Kragović M. (2016). Selected heavy metal biosorption by compost of Myriophyllum spicatum - A chemometric approach. Ecol. Eng. 93, 112-119. DOI: 10.1002/jctb.4184

Mohammadi T., Moheb A., Sadrzadeh M. and Razmi A. (2005). Modeling of metal ion removal from wastewater by electrodialysis. Sep. Purif. Technol. 41 (1), 73-82. DOI: 10.1016/j.seppur.2004.04.007

Moussavi G. and Barikbin B. (2010). Biosorption of chromium(VI) from industrial wastewater onto pistachio hull waste biomass. Chem. Eng. J. 162 (3), 893-900. DOI: 10.1016/j.cej.2010.06.032

Munagapati V.S., Yarramuthi V., Nadavala S.K., Alla S.R. and Abburi K. (2010). Biosorption of $\mathrm{Cu}$ (II), Cd(II) and $\mathrm{Pb}(\mathrm{II})$ by Acacia leucocephala bark powder: Kinetics, equilibrium and thermodynamics. Chem. Eng. J. 157 (2-3), 357-365. DOI: 10.1016/j.cej.2009.11.015
Park D., Yun Y.-S. and Park J.M. (2010). The past, present, and future trends of biosorption. Biotechnol. Bioprocess Eng. 15 (1), 86-102.

DOI: $10.1007 / \mathrm{s} 12257-009-0199-4$

Rhoads J.W. (1986). Cation exchange capacity. In: Methods of soil analysis, part 2 (Page C.A., Ed.). ASA, Madison, USA, pp. 149-158.

Salazar-Camacho C.A. and Villalobos-Peñalosa M. (2017). Characterization and surface reactivity of natural and synthetic magnetites: II. Adsorption of $\mathrm{Pb}$ (II) and Zn(II). Rev. Int. Contam. Ambie. 33 (1), 165-176.

DOI: $10.20937 /$ rica.2017.33.01.15

Šćiban M., Klašnja M. and Škrbić B. (2008). Adsorption of copper ions from water by modified agricultural by-products. Desalination. 229 (1-3), 170-180. DOI:10.1016/j.desal.2007.08.017

Singh S. and Balomajumder C. (2016). Simultaneous biosorption and bioaccumulation of phenol and cyanide using coconut shell activated carbon immobilized Pseudomonas putida (MTCC 1194). J. Environ. Chem. Eng. 4 (2), 1604-1614.

DOI: $10.1016 /$ j.jece.2016.02.011

Sparks D.L. (2003). Environmental soil chemistry. Academic Press, San Diego, USA, 352 pp.

Ullah I., Nadeem R., Iqbal M. and Manzoor Q. (2013). Biosorption of chromium onto native and immobilized sugarcane bagasse waste biomass. Ecol. Eng. 60, 99107. DOI: $10.1016 / j$.ecoleng.2013.07.028

Visual MINTEQ (2013). Visual MINTEQ - A free equilibrium speciation model. Royal Institute of Technology, Stockholm, Sweden [online]. https://vminteq.lwr.kth. se $12 / 10 / 2015$. 